\title{
STUDI PERILAKU ADAPTASI MANUSIA TERHADAP LINGKUNGAN SOSIAL DALAM PENAMBAHAN FUNGSI RUANG KOMERSIAL HUNIAN TRADISIONAL BALI DI UBUD
}

\author{
Erwin Ardianto Halim \\ (Email: halim.rwin@gmail.com ) \\ Program Studi Desain Interior \\ Fakultas Seni Rupa dan Desain \\ Universitas Kristen Maranatha \\ J. Prof. Drg. Surya Sumantri No. 65, Bandung, Indonesia
}

\begin{abstract}
ABSTRAK
Peningkatan industri pariwisata di Pulau Bali selama bertahun-tahun memiliki dampak yang sangatsignifikan pada keadaan sosial masyarakat Bali.Hal ini dapat dilihat dari perubahan perilaku masyarakat sehari-hari dari masyarakat tradisi menjadi masyarakat dengan nilai-nilai modern yang majemuk. Keinginan untuk mempertahankan kehidupan dan perilaku tradisi tetap ada pada masyarakat dan generasipenerus tradisi di Bali, namun demikian kondisi pariwisata dan tuntutan ekonomi menciptakan situasi yang sulit untuk mempertahankan keaslian tradisi dan budaya Bali. Hal ini tentu akan berdampak pada hasil-hasil budaya masa kini, salah satunya pada ruang arsitektur sebagai perwujudan masyarakatnya.Perubahan wujud ruang, khususnya hunian tradisional masyarakat Bali, terjadi terutama pada wilayah-wilayah yang terkonsentrasi untuk pariwisata, seperti wilayah Ubud.Ubud dalam rencana pengembangan wilayah Pulau Bali merupakan salah satu kawasan strategis pariwisata yang berfungsi sebagai tonggak perekonomian daerah.Perubahan wujud ruang hunian tradisional tersebut biasanya berupa penambahan atau modifikasi fungsi komersial di salah satu bagian hunian.Penelitian ini berfokus pada perubahan fungsi ruang komersial yang terdapat dalam hunian tradisional Bali di Ubud. Dalam arsitektur hunian tradisional Bali yang digunakan secara turun-temurun antar generasi, banyak nilai-nilai tradisi filosofis dan sakral yang harus dipertahankan. Oleh karena itu, permasalahan yang diteliti adalah mengenai benturan yang terjadi antara kebutuhan untuk beradaptasi dengan kontekstualitas sosio-kultural dengan menambah fungsi komersial, dengan kebutuhan untuk mempertahankan nili-nilai tradisi dan kesakralan dalam ruang hunian.Permasalahan dianalisis melalui pengolahan sistem ruang huniankomersial yaitu pada konsep pemintakatan (zoning) konsep orientasi ruang, dan kondisi batas-batas ruang pada objek studi yang diteliti.
\end{abstract}

Kata kunci: perilaku adaptasi manusia; perubahan fungsi; rumah tradisional; Ubud

\begin{abstract}
Tourism in Bali has significant effect to Balinese social aspect. It can be seen from the Balinese people daily behavior that has changed from traditional society to modern and diverse society. The conviction to conserve traditional pattern of life and behavior is still exists in the Balinese society and their posterity, but in the other side, tourism development and economical urgency creates difficult situation to conserve the purity of Balinese cultural tradition. This situations influence Balinese cultural products created nowadays, such as architectural spaces that represent the people within. The changes occurring in traditional Balinese houses happened mostly in concentrated tourism areas, such as Ubud. In the government urban development plan, Ubud is selected as one of strategic tourism point of interest that is cultural tourism. Consequently, Ubud also functions as strategic economic income resource for Bali. The changes in traditional Balinese houses mostly happened because of the need to adapt with socio-cultural context, where local tourists and expatriates come and even stay for longer time. To accommodate tourist's needs, Ubud villagers set off to open restaurants, cafes, art galleries, souvenir shops, and travel agents in their houses. These commercial areas are located in their traditional houses, with modification of rooms or even addition of rooms with other functions. This research focused on the space transformation to commercial spaces in traditional Balinese houses. There are abundant philosophical values that have to
\end{abstract}


be conserve in traditional Balinese houses between generations. Those philosophical values have sacred meanings within its design elements, such as building orientation, building elevation, facades, borders and zoning. With the addition of commercial places, how do The Ubud people managed to continue their tradition and the values within? Therefore, the main problem that is being researched here is about the collision between the need to adapt to socio-cultural context in the society and the need to conserved cultural traditions in the family and their sacred meanings.

Keywords: human adaptative behaviour; space transformation; traditional house; Ubud

\section{PENDAHULUAN}

Bali sebagai daerah tujuan wisata favorit di Indonesia saat ini menarik banyak wisatawan mancanegara untuk berlibur bahkan akhirnya berdomisili secara temporer maupun permanen. Interaksi multikultural yang terjadi di Pulau Dewata tersebut semakin lama kian kompleks, bahkan pada beberapa tempat seperti di Kuta dan Sanur, "local content" dari Bali sendiri terasa kian pudar, berganti dengan image-image global dengan nilai-nilai yang lebih universal.

Kondisi ini kian lama semakin mendorong berkembangnya budaya global yang sama sekali berbeda dengan budaya tradisional Bali. Masyarakat tradisional Bali yang bermatapencaharian petani telah berganti menjadi masyarakat global yang berorientasi pada bisnis pariwisata. Demikian pula struktur pedesaan di Bali dengan areal persawahan yang hijau, kini sedikit demi sedikit telah berubah rupa menjadi kawasan perkotaan yang juga merupakan kawasan tujuan wisata. Wilayah Ubud di Bali yang sedianya merupakan desa petani, kini telah berubah menjadi kawasan metropolitan Sarbagita, bersama dengan kota Denpasar; Mengwi, Abiansemal, dan Kuta di Kabupaten Badung; Sukawati, Blahbatuh, Ubud, dan Gianyar di Kabupaten Gianyar; dan Tabanan di Kabupaten Tabanan.

Kawasan metropolitan Sarbagita merupakan daerah yang memiliki potensi pariwisata yang dikembangkan untuk keperluan industri pariwisata. Ubud dengan keindahan panoramanya dan kultur masyarakatnya yang unik memang sejak zaman kolonial telah menarik wisatawan mancanegara untuk berlibur bahkan menetap di sana.

Interaksi multikultural yang terjadi di Pulau Bali berawal dari merapatnya armada kapal De Houtman pada tahun 1597, yang diikuti dengan perpecahan beberapa kerajaan di Bali pada abad ke-17, dan pemberontakan-pemberontakan terhadap penjajahan Belanda pada abad ke-19 yang diakhiri dengan terintegrasinya kerajaan-kerajaan di Bali secara administratif dalam Pemerintahan Kolonial Belanda. Sebagaimana Bali kemudian terbuka terhadap dunia, maka dunia secara umum seperti menemukan Bali. Dapat dikatakan bahwa dunia 
terpesona terhadap keindahan pulau ini, sehingga berbagai upaya dilakukan untuk mentransformasikan Bali sehingga menjadi lebih baik. Sayangnya, sedaya upaya yang dilakukan berdampak positif dan juga negatif, salah satunya adalah menjadikannya tidak murni sebagaimana telah terjadi sekarang. Hal ini ditambah dengan pencanangan Bali sebagai daerah tujuan wisata utama di wilayah Indonesia Tengah pada tahun 1970-an oleh pemerintahan Presiden Soeharto.

Perkembangan ini mendorong perubahan yang terjadi pada wilayah pemukiman penduduk tradisional Ubud. Oleh karena tuntutan sosial dan ekonomi, rumah-rumah penduduk yang sedianya merupakan ruang hunian saja, kini telah mengalami perkembangan fungsi tambahan komersial, antara lain: penginapan, jasa perjalanan, rumah makan, cafe, dan toko/warung serba ada. Adanya fungsi ruang komersial memungkinkan terjadinya perubahan wujud ruang dari wujud asli tradisinya. Padahal dalam sebuah arsitektur tradisional, khususnya ruang hunian, banyak sekali nilai-nilai filosofis yang terkandung di dalamnya. Oleh karena itu, sangat mungkin terjadi perubahan atau pengabaian nilai-nilai tradisi yang telah diwariskan oleh penghuni secara turun-temurun.

Berdasarkan pemaparan latar belakang dan kondisi pembaruan yang terjadi di Bali, maka penelitian dibatasi pada daerah Ubud sebagai tempat studi kasus dengan rumusan sebagai berikut:

- Apakah yang menjadi pertimbangan utama dalam penambahan fungsi ruang komersial pada rumah tradisional Bali di Ubud, mengingat terdapatnya benturan antara kebutuhan terhadap kontekstualitas sosio-kultural dengan kontinuitas dan preservasi tradisi?

- Apakah adanya penambahan fungsi ruang komersial pada rumah tradisional Bali di Ubud menyebabkan perubahan ruang dan nilai-nilai tradisi?

Kedua pertanyaan penelitian tersebut, akan menjawab tujuan penelitian sebagai berikut:

- Mengetahui perilaku penduduk Bali di Ubud dalam menyikapi ruang huniannyasebagai makhluk sosial yang harus beradaptasi dengan lingkungan sekelilingnya dan sebagai makhluk budaya yang harus mempertahankan tradisi/norma yang dianutnya.

- Mengetahui perubahan elemen ruangapa saja yang terjadi dalam hunian dari wujud tradisionalnya dan nilai-nilai apa saja yang berubah atau diabaikan dari tradisi sebelumnya. 
Baik kedua pertanyaan penelitian dan tujuan penelitian akan menghasilkan manfaat berupa:

- Menambah pengetahuan dalam bidang kajian ilmu desain interior yang mempelajari perilaku manusia dan lingkungan (environmental behaviour) lokal di Indonesia, mengingat penelitian dalam bidang kajian tersebut di Indonesia masih sangat kurang.

- Merupakan penelitian awal yang dapat menjadi track-record peneliti dalam melakukan penelitian lanjutan di bidang kajian perilaku manusia dan ruang.

\section{METODE PENELITIAN}

Penelitian merupakan penelitian deskriptif kualitatif yang berupaya mencari makna interpretatif dari bentuk visual objek. Untuk pelaksanaannya, dibutuhkan data-data sebagai berikut:

a. Data Literatur / Pustaka

- Data arsitektur tradisional Bali dengan nilai-nilai filosofis yang terkandung di dalamnya.

- Data mengenai konsep hubungan sosial dalam masyarakat Bali.

- Data mengenai wilayah Ubud dan peraturan daerah yang menyangkut aspek pariwisata.

- Teori mengenai perilaku manusia dan ruang (environmental behavior) terutama mengenai makna ruang hunian dan proses adaptasi manusia.

b. Data Survei Lapangan

- Data fisik bangunan dan dokumentasi fisik berupa denah layout yang menunjukkan batas-batas dan bukaan ruang, vegetasi, olahan landscape, dan akses serta sirkulasi.

- Data wawancara dengan penghuni rumah sebagai penentu keputusan ruang berkaitan dengan keberadaan fungsi komersial di dalam rumah mereka.

Sampel penelitian diambil beberapa bangunan rumah tradisional Bali pada wilayah Ubud yang sudah mengalami penambahan fungsi komersial pariwisata dipilih berdasarkan:

- hubungan kedekatan secara fisik (lokasi) dengan Puri Saren sebagai patron tradisi masyarakat Ubud, yang diasumsikan akar tradisi Bali masih dipegang kuat oleh para penghuni rumah tersebut.

- lokasi potensi pariwisata yang strategis untuk pengadaan fasilitas komersial pendukung aktivitas pariwisata, yang diasumsikan pada wilayah ini kedatangan turis dan kontak yang terjadi cukup intens. 
Metode analisis data dilakukan dengan cara:

a. Menganalisis perubahan yang terjadi pada sampel bila dibandingkan dengan rumah tradisional Bali.

b. Membandingkannya dengan nilai-nilai arsitektur tradisional Bali.

C. Menganalisis perubahan nilai-nilai filosofis pada arsitektur tradisional Bali yang terjadi akibat dari perubahan dan penambahan fungsi komersial tersebut.

\section{PEMBAHASAN}

Melihat fenomena yang ada seperti yang telah dijelaskan di atas, maka penulis memberikan perbandingan kondisi awal dan kondisi saat ini.

Berikut penjabaran landasan filosofi umum rumah tinggal masyarakat Bali:

Bagi masyarakat Bali rumah tinggal merupakan perwujudan dari tata kehidupan yang bersumber dari agama Hindu, manusia sebagai mikrokosmos dan keseluruhan alam sebagai makrokosmos. Manusia sebagai bagian dari alam dan akan selalu bergantung pada alam, manusia sebagai bhuana alit dan alam sebagai bhuana agung. Konsep ini pula yang dilambangkan oleh 'manik ring cecupu' yang artinya janin di dalam rahim, dengan manusia yang dilambangkan dengan 'janin' akan selalu bergantung pada 'rahim' yaitu alam lingkungannya.

Ada beberapa konsep tradisi yang menjadi dasar filosofis arsitektur tradisional Bali:

a. Rwa Bhineda

Konsep ini memberikan kesadaran dalam kehidupan di dunia tentang dikotomi yang bersifat kodrati seperti baik-buruk, siang-malam, pria-wanita, sakral-profan, hulu-hilir, luan-teben, ditegaskan dalam kitab Sarasamuscaya, Seloka 498, artinya: Dua hal yang berbeda, seperti suka dan duka tidak dapat disingkirkan dari kehidupan ini, merupakan kekuasaan Sang Hyang Widhi Wasa atau Tuhan, sehingga segala mahluk tidak luput dari ikatan suka maupun duka dalam kehidupannya (Kanjeng, 1994: 381).

b. Tat Twam Asi

Artinya falsafah sebagai hakikat terdalam dalam agama Hindu, berasal dari kata 'tat' artinya itu dan 'twa' artinya hakikat atau sifat, dan 'asi' artinya itu. Sehingga tat twa berarti hakikat atau sifat itu (majelis Pembinaan Lembaga Adat, 1992: 25). Manusia dan alam semesta adalah ciptaan Sang Hyang Widhi Wasa sebagai dunia makro dan mikro yang saling berkaitan dan selaras. Kedua ciptaan ini terdiri atas lima unsur (Panca Maha 
Butha) yaitu: udara (bayu), gas (akasa), cahaya (teja), zat cair (apah), dan zat padat (pratiwi).

\section{c. Tri Hita Karana}

Artinya tiga unsur sumber kebaikan, merupakan gabungan antara unsur jasmani, jiwa dan tenaga yang mempunyai hubungan yang harmonis. Hubungan ini juga bisa diidentikkan dengan:

- hubungan manusia dengan Tuhan (Pencipta, Pemelihara, Pemusnah).

- hubungan manusia dengan manusia (sesamanya) yakni: jiwa, fisik, tenaga.

- hubungan manusia dengan lingkungannya.

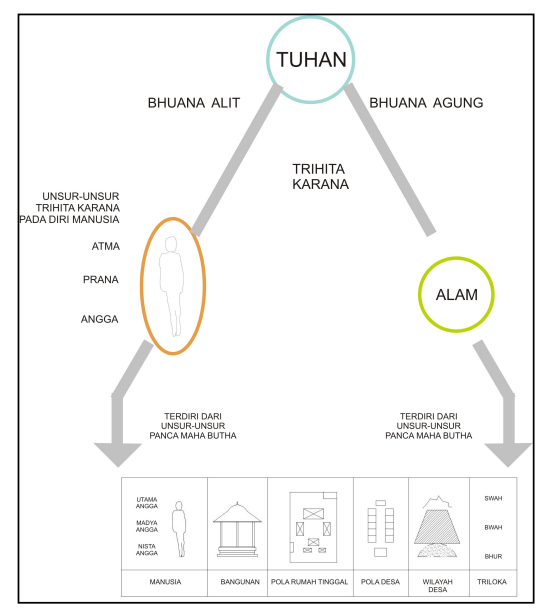

Gambar 1. Bagan Konsep Tri Hita Karana Sumber: dokumen Pribadi Peneliti; 2009

Konsep tiga unsur yang saling berkaitan ini (Tri Angga) diterapkan pula pada setiap aspek hidup dan lingkungan manusia:

- pada fisik manusia, yaitu: kepala, badan, kaki

- pada alam, yaitu: alam atas, tengah, dan bawah

- pada tata lingkungan, yaitu: gunung, daratan, lautan

- pada desa adat, yaitu: tempat peribadatan, hunian, kuburan

- pada arsitektur, yaitu: atap, dinding, pondasi.

d. Catur Muka

Merupakan perpotongan dua sumbu orientasi yaitu sumbu religi pada arah kangin-kauh (Barat-Timur) dan dan sumbu bumi kaja-kelod (Utara-Selatan) untuk Bali Selatan dan Selatan-Utara untuk Bali Utara. 


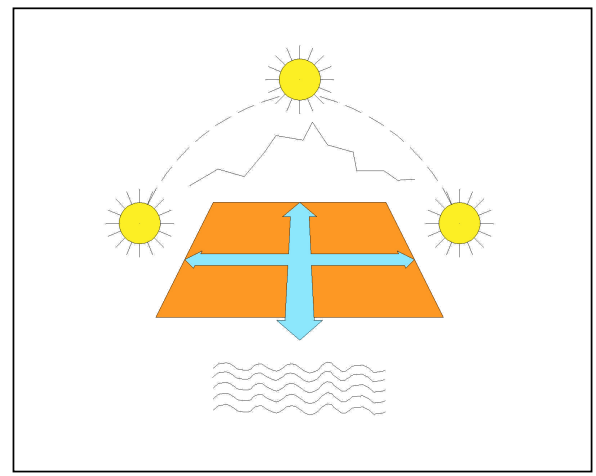

Gambar 2. Konsep Kaja-Kelod Sumber: dokumentasi peneliti, 2009

\section{e. Sanga Mandala}

Merupakan perpaduan antara konsep Sumbu Bumi (Kaja-Kelod) dan Sumbu Religi (Kangin-Kauh). Di sini diterapkan pula konsep Tri Angga yang membagi garis sumbu ini menjadi tiga bagian. Pada arah Kaja-Kelod dibagi menjadi gunung, daratan dan lautan. Pada arah Kangin-Kauh dibagi berdasarkan peredaran matahari terbit hingga tenggelam menjadi: matahari terbit, matahari tepat di atas kepala, dan matahari tenggelam. Pembagian ini kemudian digabungkan menjadi sembilan bagian yang disebut Sanga Mandala.

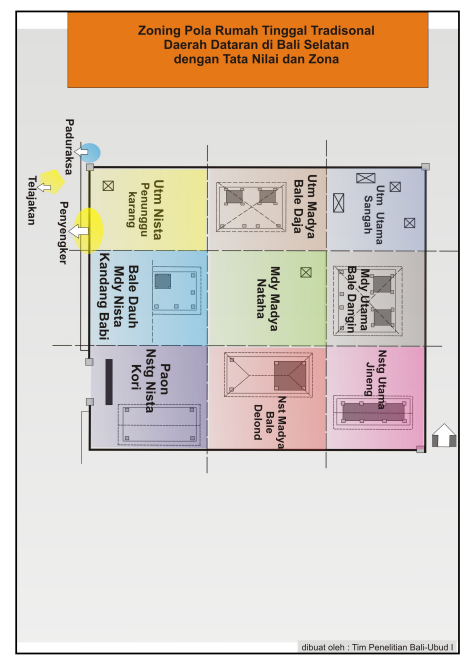

Gambar 3. Zoning Sanga Mandala pada Rumah Tradisional di Bali Selatan. Sumber: dokumentasi peneliti, 2009

Dalam rumah tinggal tradisional masyarakat Bali, memiliki tata ruang dan rata nilai rumah tinggal tradisional yang masih diperhatikan.

Konsep hidup yang berdasarkan ajaran agama Hindu ini diterapkan oleh masyarakat Bali dalam arsitektur mulai dari area yang terluas yaitu alam lingkungan, tata desa, organisasi bangunan hingga ke dalam ruang hunian dalam rumah tinggal. Tata ruang yang dimaksud 
di sini adalah pengorganisasian ruang berdasarkan fungsi dan aktivitas di dalamnya serta nilai yang berlaku.

Rumah tinggal dibagi menjadi tiga bagian berdasarkan konsep Sangga Mandala, mulai dari utamaning utama sampai dengan nistaning nista, kemudian dibagi lagi ke dalam tiga kelompok berdasarkan konsep Trihita Karana yang diaplikasikan dalam Tri Angga menjadi 3 zona, yaitu:

a. zona parhyangan (kepala, area sanggah atau merajan sebagai tempat pemujaan). Berada di arah timur laut (kaja-kangin), menempati nilai utamaning utama, mempunyai nilai sakral, diperuntukkan bagi bangunan suci, seperti sanggah untuk orang jaba dan pemerajan untuk kaum ningrat.

b. zona pawongan (badan, area natah atau halaman tengah untuk ruang hunian, melakukan upacara dan kegiatan sosial lainnya). Terdiri dari beberapa bangunan pola jamak seperti:

- Bale daja, disebut juga bale meten, bale bandung, atau tergantung pada jumlah tiang yang dimilikinya. Pola bangunan tertutup sebagai tempat untuk tidur dan menyimpan barang-barang berharga (benda pusaka), berorientasi ke natah (tengah).

- Bale dangin, menempati arah tengah-kangin, mempunyai nilai utamaning madya. Bale ini berorientasi ke natah dan memiliki pola ruang terbuka. Fungsinya sebagai ruang tidur anak laki-laki dewasa atau bapak sebagai kepala rumah tangga dan untuk upacara adat. Peletakan kolom diatur sehingga salah satu jajaran tiangnya membentuk garis lurus dengan salah satu jajar tiang bale meten.

- Bale delod, menempati arah selatan mempunyai nilai nistaning madya. Merupakan bangunan multifungsi sebagai tempat untuk upacara adat maupun aktivitas lain. Disebut juga bale sumanggen.

- Bale dauh, menempati arah Barat, mempunyai nilai madyaning nista. Merupakan tempat kerja, menerima tamu, dan tidur.

- Paon, menempati arah Barat Daya, mempunyai nilai nistaning nista. Selain sebagai area servis, seperti memasak, makan dan lain-lain, juga bernilai spiritual sebagai pelebur. Dengan adanya api atau tungku perapian, paon dianggap tempat untuk melebur roh jahat yang masuk ke dalam pekarangan rumah tinggal.

- Jineng, menempati arah Tenggara, mempunyai nilai nistaning utama, berfungsi sebagai lumbung tempat menyimpan padi, sekaligus digunakan juga untuk tempat beristirahat. 
- Natah, menempati area tengah, merupakan pusat orientasi rumah tinggal, berupa ruang terbuka yang ditutup dengan dinding semipermanen yang dapat dibuka jika akan dilangsungkan upacara adat.

- Penunggu Karang, menempati arah Barat Laut dan merupakan area yang dipersembahkan bagi penunggu karang, untuk menjaga keseimbangan alam dan lingkungan, serta penjagaan terhadap hal-hal dari luar yang membawa pengaruh buruk. Area ini mempunyai nilai utamaning nista.

c. zona palemahan (kaki, area lebuh untuk meletakkan bahan-bahan yang tak terpakai lagi, lahan peternakan dan pertanian). Menempati arah Barat, mempunyai nilai nistaning utama sampai dengan madya, merupakan area depan dari rumah tinggal tradisional, dipercaya sebagai area peralihan antara baik dan buruk, skala dan niskala, dan lain-lain. Pada area ini terdapat:

- Pintu masuk pekarangan kori agung untuk tempat-tempat yang diagungkan.

- Pagar (panyengker) adalah batas pekarangan yang dapat berupa pagar hidup ataupun pagar tembok. Untuk bangunan suci pemujaan, pekarangannya memanjang kangin-kauh, sedangkan untuk perumahan memanjang kaja-kelod.

- Paduraksa.

- Telajakan, sebagai batas antara halaman rumah dan jalan, biasa ditanami tanaman obat atau bunga.

- Kandang babi atau kandang ternak.

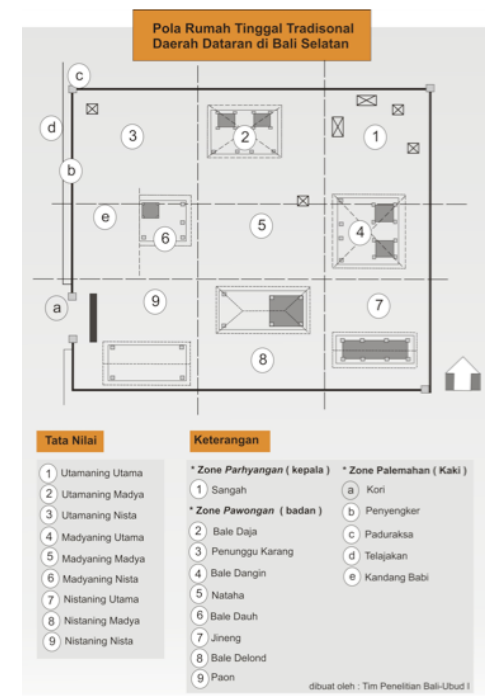

Gambar 4. Pembagian Area berdasarkan Hierarki Kesakralan pada Rumah Tradisional Bali Selatan Sumber: dokumentasi peneliti, 2009 
Analisis permasalahan penelitian, yaitu analisis tentang perubahan ruang apa yang terjadi pada rumah yang menjadi studi kasus dan analisis nilai-nilai filosofis tradisional yang berubah atau telah bergeser di dalamnya. Analisis dilakukan dengan cara:

a. Membandingkan zoning pada denah bangunan saat ini dan kemudian dibandingkan dengan pola pembagian ruang tradisional Bali, yaitu penggunaan konsep Rwa Bhinneda, Tri Hita Karana, dan Sanga Mandala

b. Menganalisis ruang-ruang apa saja yang berubah, bertambah, ataupun berkurang dari fungsi hunian semula, terutama yang berfungsi sebagai ruang komersial.

Penelitan ini mengambil tiga rumah yang menjadi objek pembahasan, adapun rumah yang dimaksud sebagai berikut:

\section{Studi Kasus 1}

\section{Savannah Moon, Jl. Kanjeng No.18, Ubud-Bali}

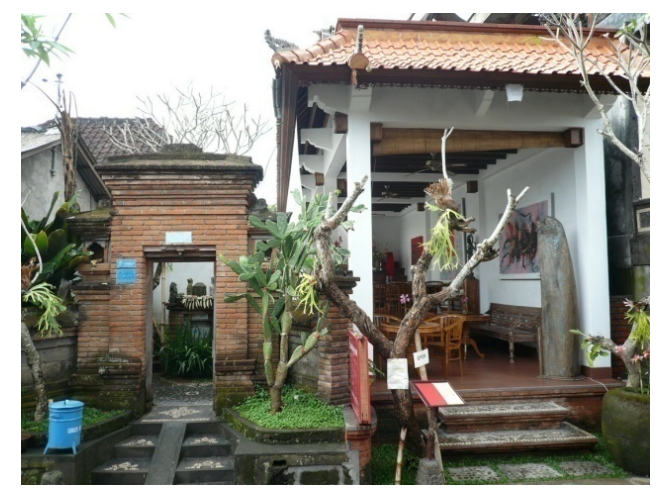

Gambar 5. Fasade Savannah Moon menunjukkan kondisi gerbang dan fungsi komersial restaurant yang terletak di bagian barat lahan hunian

Sumber: dokumentasi peneliti, 2009

Penambahan ruang komersial pada Savannah Moon diupayakan berada di luar zona Sanga Mandala.Penambahan ruang komersial diusahakan tidak memasuki area yang termasuk dalam zona Sanga Mandala.Dalam kasus ini, penghuni berusaha menempatkannya pada area telajakan, sehingga mengakibatkan hilangnya batas-batas hunian, yaitu tembok panyengker, paduraksa, dan kandang babi.Namun demikian, akibat tuntutan kebutuhan ruang, sebagian lahan di bagian barat (terutama pada area madyaning nista/bale dauh dan area nistaning nista/paon) terpakai sebagai area komersial dan berubah fungsi. Sedangkan orientasi fungsi komersial terjadi ke dua arah, yaitu ke arah jalan Kajeng dan ke dalam 
natah, karena adanya studio/galeri lukisan dan kafe. Hal ini menyebabkan teritori hunian dan konsep nilainya bercampur dengan fungsi komersial.

( lihat Lampiran; Tabel 1.1 Perubahan Nilai)

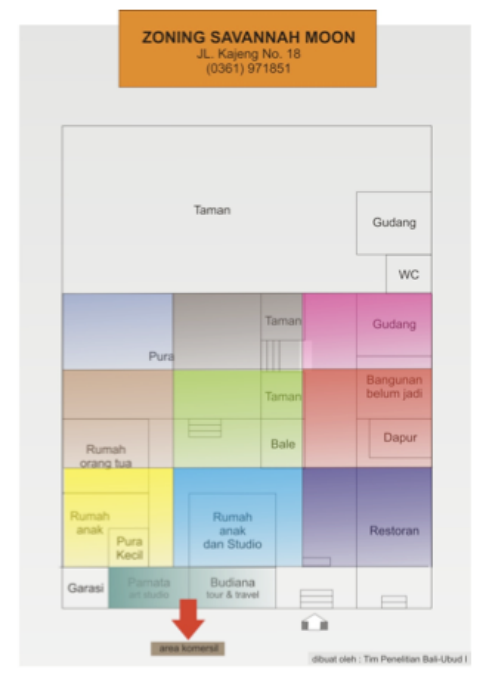

Gambar 6. Zoning dan pembagian area menurut pola Sanga Mandala pada Rumah Savannah Moon Sumber: dokumentasi peneliti, 2009

Pada rumah Savannah Moon ini terdapat penambahan ruang komersial berupa café/restaurant, galeri lukisan, dan biro perjalanan. Kesemua ruang komersial ini terletak di bagian depan rumah, yaitu di sebelah barat. Akibat dari penambahan ruang komersial tersebut, pawon yang seharusnya terletak pada bagian restaurant berpindah tempat ke area madyaning nista. Perubahan lain yang tampak jelas adalah tidak jelasnya batas-batas tembok panyengker dan paduraksa, yang tersisa hanyalah angkul-angkul (gerbang) dan aling-aling. Ruang yang berubah fungsi pada rumah ini dapat dilihat dalam Tabel 1 berikut ini:

Tabel 1. Tabel Perubahan Fungsi Ruang pada Rumah Savannah Moon

\begin{tabular}{|l|l|}
\hline Area dan Fungsi Tradisionalnya & Fungsi yang Terjadi Saat Ini \\
\hline Bale Delod, multifungsi sebagai tempat untuk upacara adat maupun aktivitas lain & Dapur \\
\hline Paon & Area komersial: kafe \\
\hline Jineng, berfungsi sebagai lumbung & Gudang, service \\
\hline Bale Daja/Meten, untuk tempat tidur dan menyimpan benda pusaka & Rumah orangtua \\
\hline $\begin{array}{l}\text { Bale Dauh, untuk tempat bekerja di siang hari, digunakan pula untuk tidur di malam } \\
\text { hari }\end{array}$ & Studio/galeri lukisan \\
\hline $\begin{array}{l}\text { Bale Dangin, untuk upacara keagamaan, tempat tidur kepala keluarga, dan } \\
\text { penyimpanan peralatan upacara }\end{array}$ & $\begin{array}{l}\text { Penyimpanan peralatan } \\
\text { dan lukisan }\end{array}$ \\
\hline \begin{tabular}{l} 
Penunggu karang \\
Penunggu karang dan \\
\hline
\end{tabular}
\end{tabular}

Sumber: dokumentasi peneliti, 2009 


\section{Studi Kasus 2}

\section{Bali Yoga, Jl. Kanjeng No. 11, Ubud -Bali}

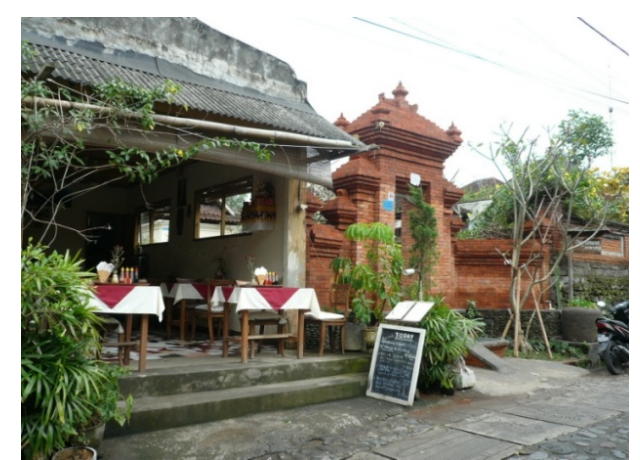

Gambar 7. Area gerbang dan ruang komersial restaurant/café yang terletak di bagian depan (timur, tenggara) Bali Yoga

Sumber: dokumentasi peneliti, 2009

Area komersial terletak pada zona "nistaning utama" atau "jineng" (kafe) dalam Sanga Mandala dan kebon (homestay) di luar Sanga Mandala. Penempatan restaurant sesungguhnya telah mengubah tradisi tata ruang rumah tradisional Bali yang sedianya diperuntukkan sebagai lokasi lumbung.Lumbung pada hunian ini sudah tidak ada lagi disebabkan oleh perubahan mata pencaharian penghuni yang sudah tidak bertani lagi.Sedangkan homestay yang ditempatkan pada bagian kebon tidak mengganggu pola tata ruang rumah tradisional, karena kebon pada umumnya dimanfaatkan untuk keperluan tersier tergantung kebutuhan penghuni.Sedangkan orientasi restaurant ke arah muka tidak mengakibatkan terusiknya konsep nilai, namundemikian keberadaan homestay di kebon mencampuradukkan fungsi hunian yang private dengan public. Hal ini disebabkan oleh akses menuju ke dalam hunian hanya ada satu buah, yaitu melalui angkul-angkul/gerbang.

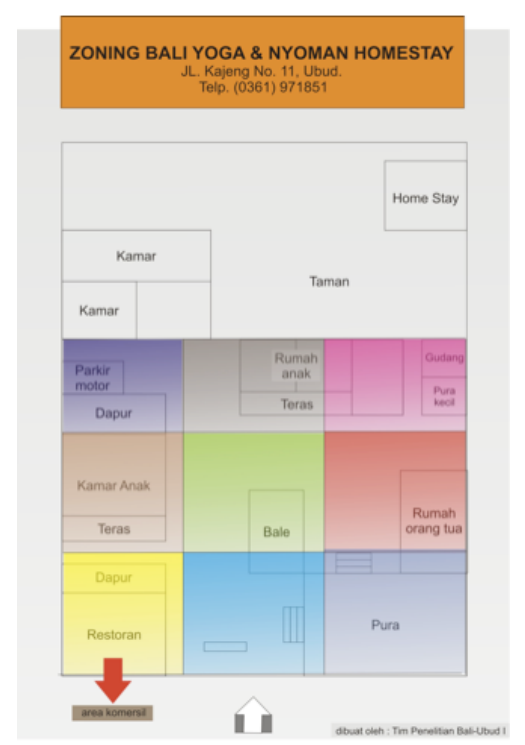


Gambar 8. Zoning dan pembagian area menurut pola

Sanga Mandala pada Rumah Bali Yoga

Sumber: dokumentasi peneliti, 2009

lihat Lampiran; Tabel 1.2 Perubahan Zoning

Pada rumah Bali Yoga ini terdapat penambahan ruang komersial berupa café/restaurant dan homestay/penginapan café/restaurant terletak di bagian depan rumah, yaitu pada bagian timur lahan, sedangkan homestay/penginapan berada di bagian barat lahan. Homestay/penginapan berada di luar area Sanga Mandala, sedangkan café/restaurant ternyata menempati area nistaning utama/jineng.Pada rumah ini, tembok panyengker dan paduraksa masih terlihat jelas batas-batasnya. Demikian pula gerbang dan aling-aling masih dipertahankan, walaupun sudah mengalami modifikasi untuk jalan masuk motor (penambahan ramp dan pelebaran ukuran gerbang). Sedangkan untuk ruang-ruang yang berubah fungsi pada rumah ini dapat dilihatdalam Tabel 2 berikut ini: (Lihat Lampiran ; Tabel 1.3 Perubahan Ruang)

Tabel 2. Table Perubahan Fungsi Ruang pada Rumah Bali Yoga

\begin{tabular}{|l|l|}
\hline Area dan Fungsi Tradisionalnya & Fungsi yang Terjadi Saat Ini \\
\hline $\begin{array}{l}\text { Bale Delod, multifungsi sebagai tempat } \\
\text { untuk upacara adat maupun aktivitas lain }\end{array}$ & Rumah Anak \\
\hline Paon & Dapur/service \\
\hline Jineng, berfungsi sebagai lumbung & Café/restaurant \\
\hline $\begin{array}{l}\text { Bale Daja/Meten, untuk tempat tidur dan } \\
\text { menyimpan benda pusaka }\end{array}$ & Rumah Orangtua \\
\hline $\begin{array}{l}\text { Bale Dauh, untuk tempat bekerja di siang } \\
\text { hari, digunakan pula untuk tidur di malam } \\
\text { hari }\end{array}$ & Rumah Anak \\
\hline $\begin{array}{l}\text { Bale Dangin, untuk upacara keagamaan, } \\
\text { tempat tidur kepala keluarga, dan } \\
\text { penyimpanan peralatan upacara }\end{array}$ & Tempat penyimpanan peralatan \\
\hline \begin{tabular}{l} 
Penunggu karang \\
\hline
\end{tabular} & Penunggu karang dan gudang \\
\hline
\end{tabular}

Sumber: dokumentasi peneliti, 2009 


\section{Studi Kasus 3}

\section{Oka's Warung, Jl. Kanjeng No.2, Ubud-Bali}

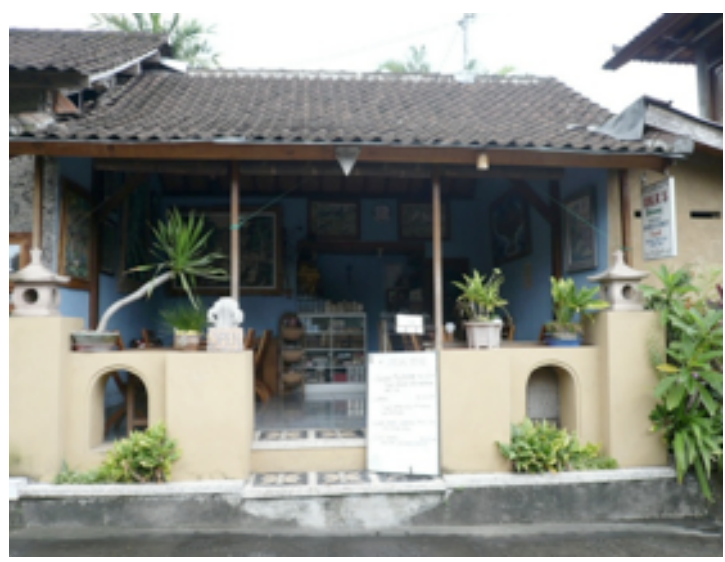

Gambar 9. Area komersial pada bagian muka rumah Oka's Warung, hanya menyisakan angkul-angkul yang terlihat

Sumber: dokumentasi peneliti, 2009

Area komersial terletak di luar Sanga Mandala, yaitu pada bagian telajakan, sehingga konsep pola Sanga Mandala tidak terusik. Namun demikian, akibat dari adanya area komersial tersebut, batas-batas hunian seperti tembok panyengker, kandang babi, paduraksa sudah tidak terlihat sama sekali. Area komersial ini juga seluruhnya berorientasi ke Jl. Kajeng sehingga tidak mengusik konsep nilai natah.Penambahan ruang yang berubah fungsi pada zona Sanga Mandala adalah kamar-kamar anggota keluarga dan pergeseran fungsi lumbung menjadi dapur, tidak ada kaitan langsung dengan fungsi ruang komersial. (Lihat Lampiran: Tabel 1.2 Perubahan Zoning)

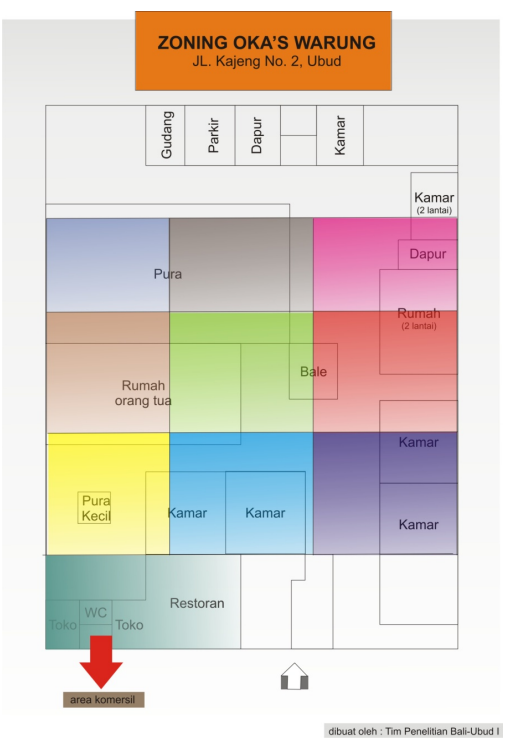

Gambar 10. Zoning dan pembagian area menurut pola Sanga Mandala pada Rumah Oka's Warung Sumber: dokumentasi peneliti, 2009 
Pada rumah Oka's Warung ini terdapat penambahan ruang komersial berupa café/restaurant dan biro perjalanan.Café dan biro perjalanan tersebut terletak di bagian depan rumah, yaitu pada bagian timur lahan. Pada rumah ini, tembok panyengker dan paduraksa telah hilang batas-batasnya, berganti dengan deretan ruang komersial.Namun demikian gerbang masih dipertahankan, walaupun aling-aling sudah tidak ada lagi. Di bagian dalam ruang hunian (natah), terdapat banyak perubahan fungsi ruang dan penambahan kamar-kamar, namun tidak ada sangkut-pautnya dengan kebutuhan ruang komersial, melainkan karena penambahan jumlah anggota keluarga. Ruang-ruang yang berubah fungsi pada rumah ini dapat dilihat dalam Tabel 3 berikut ini:

Tabel 3. Perubahan Fungsi Ruang pada Rumah Oka's Warung

\begin{tabular}{|l|l|}
\hline $\begin{array}{l}\text { Area dan Fungsi } \\
\text { Tradisionalnya }\end{array}$ & $\begin{array}{l}\text { Fungsi yang Terjadi } \\
\text { Saat Ini }\end{array}$ \\
\hline $\begin{array}{l}\text { Bale Delod, multifungsi sebagai } \\
\text { tempat untuk upacara adat } \\
\text { maupun aktivitas lain }\end{array}$ & Rumah anak \\
\hline $\begin{array}{l}\text { Paon } \\
\text { Jineng, berfungsi sebagai } \\
\text { lumbung }\end{array}$ & Dapur \\
\hline $\begin{array}{l}\text { Bale Daja/Meten, untuk tempat } \\
\text { tidur dan menyimpan benda } \\
\text { pusaka }\end{array}$ & Rumah Orangtua \\
\hline $\begin{array}{l}\text { Bale Dauh, untuk tempat bekerja } \\
\text { di siang hari, digunakan pula } \\
\text { untuk tidur di malam hari }\end{array}$ & Rumah Anak \\
\hline $\begin{array}{l}\text { Bale Dangin, untuk upacara } \\
\text { keagamaan, tempat tidur kepala } \\
\text { keluarga, dan penyimpanan } \\
\text { peralatan upacara }\end{array}$ & $\begin{array}{l}\text { Tempat penyimpanan } \\
\text { peralatan }\end{array}$ \\
\hline \begin{tabular}{l} 
Penunggu karang \\
\hline Sumber: dokumentasi
\end{tabular} & Penunggu karang \\
\hline
\end{tabular}

Sumber: dokumentasi peneliti, 2009

\section{Analisis Perubahan Nilai}

Analisis yang terakhir adalah analisis perubahan nilai pada ketiga objek penelitian ini, pada analisis nilai ini konsep Rwa Bhineda, konsep Tri Hita Karana, konsep Sanga Mandala ditemukan bahwa masyarakat Bali tetap masih mempertahankan nilai tradisional dari tiga konsep diatas, sebagai contoh: konsep dualisme (Konsep Rwa Bhineda) yang menempatkan area sakral dan nista pada zona hunian yang berseberangan masih dipertahankan. Terlihat dari penempatan pura yang masih berorientasi kearah Gunung Agung sebagai orientasi sakral. Untuk keterangan lebih detil peneliti membuat bagan.(lihat Lampiran; Tabel 1.1 Tabel Perubahan Nilai) 


\section{PENUTUP}

Dari analisis yang telah dilakukan pada ketiga studi kasus yang dipilih, didapatkan beberapa simpulan sebagai berikut:

a. Tuntutan ekonomi dan sosial dari perkembangan pariwisata menyebabkan kontekstualitas sosio-kultural merupakan pertimbangan utama dalam perkembangan ruang hunian di Ubud masa kini, mengalahkan makna kontinuitas tradisi yang ingin dipertahankan.

b. Benturan yang terjadi akibat keadaan tarik-menarik antara kontekstualitas sosio-kultural dengan kontinuitas tradisi mengakibatkan penambahan fungsi komersial yang terjadi pada ruang hunian memiliki pola sebagai berikut:

- Fungsi komersial mulanya diusahakan untuk berada di luar zona Sanga Mandala (telajakan atau kebon). Apabila terpaksa 'menjajah' Sanga Mandala, maka zona yang paling tidak sakral (nista/madya) yang dikorbankan paling dahulu. Namun efek berantainya mengakibatkan perubahan fungsi pada ruang/zona lainnya.

- Konsep Rwa Bhinneda dan Tri Hita Karana pada tiga rumah yang dipilih sebagai objek penelitian ini terlihat pemilik rumah berusaha untuk menempatkan ruang lama maupun baru sesuai dengan nilai sakral yang diberikan pada dua konsep di atas. Namun, karena adanya penambahan ruang komersil yang ada sedikit banyak mempengaruhi zoning ruang. Nilai kedua konsep ini memiliki keterkaitan yang cukup kuat dalam pengambilan keputusan pemilik rumah dalam penambahan ruang yang baru di dalam kawasan rumah mereka.

Berdasarkan simpulan diatas, maka dapat disarankan bahwa adanya perubahan fungsi ruang dan nilai/makna yang ada di dalamnya merupakan hal yang patut disayangkan.Kontekstualitas dengan perkembangan sosio-kultural merupakan suatu aspek hakiki yang terdapat dalam seluruh lapisan kehidupan masyarakat.Namun demikian, usaha untuk mengimbangi kontekstualitas tersebut, hendaknya tidak mengorbankan kontinuitas tradisi makna. Dalam perkembangan kebutuhan dengan tuntutan zaman yang tak dapat dihindari, masyarakat tradisi di seluruh Indonesia dapat meniru langkah-langkah yang diusahakan oleh penghuni rumah Ubud pada studi kasus penelitian ini, yakni berusaha mempertahankan makna dan tradisi kesakralan dengan mengubah ruang pada zona yang paling tidak sakral (tidak penting). 


\section{DAFTAR PUSTAKA}

Couteau, Jean. (1999). Museum Puri Lukisan. Ratna Wartha Foundation, Ubud-Bali.

Karso, Olih Solihat. (1999). Perubahan Nilai Pada Arsitektur Tradisional Bali. Program Magister Seni Rupa dan Desain. Program Pascasarjana Institut Teknologi Bandung.

Kelurahan Ubud. (2006). Profil Kelurahan Ubud. Bali, Indonesia.

Pemerintah Daerah Propinsi Bali. (2009). Rencana Tata Ruang Wilayah Propinsi Bali. Bali, Indonesia.

Remawa, A. A. Gde Rai. (1998). Standarisasi Bangunan Rumah Tinggal Sebagai Pengembangan Tata Ruang Dalam (Interior) pada Arsitektur Tradisional Bali (Studi Kasus: Bale Gede/Saka Roras). Program Magister Seni Rupa dan Desain. Program Pascasarjana Institut Teknologi Bandung.

Tognoli, Jerome. Residential Enviroments. Psychological Enviroment, Chapter 17. 